\section{Olga Navrátilová}

DOI: $10.14746 /$ bo.2020.4.1

Masarykova univerzita

\section{Pavel Kosek}

Masarykova univerzita

\section{Radek Čech}

Ostravská univerzita

\section{Martin Horák}

Farní sbor Českobratrské církve evangelické v Brně

\section{Slovosled pronominálních forem mi, ti, si, ho, mu v Bibli kralické a otázka míry vlivu původních předloh ${ }^{1}$}

Keywords: Kralice Bible, pronominal enclitics, word order, influence of Latin/Greek/ /Hebrew pretext

Klíčová slova: Bible kralická, pronominální enklitika, slovosled, vliv latinské/řecké/hebrejské předlohy

\section{Abstract}

The present study focuses on the word order of the pronominal enclitics $m i, t i, s i$ ho, $m u$ in selected books of the Old and New Testaments of the Kralice Bible. It focuses mainly on the distribution of individual forms within two competing positions, i.e. the post-initial position and contact position. The paper concentrates on non-post-initial positions of enclitics in the Kralice Bible, which are significantly less frequent than the post-initial positions and are in fact variants of the contact position. In the article, we try to pinpoint the extent to which the word order of the original texts (Latin, possibly Hebrew and Greek) influences the word order of the translations, the ess frequent enclitics positions in particular. We look at Old and New Testaments separately, given that they are based on different languages.

Příspěvek vznikl v rámci řešení grantového projektu Vývoj českých pronominálnich enklitik (GA17-02545S) 2017-2019. Studie je součástí rozsáhlejšího a detailnějšího výzkumu vývoje českých pronominálních enklitik a navazuje tak na starší práce zabývající se slovosledem zájmenných forem ve starších biblických překladech (Kosek, Čech, Navrátilová 2018a, 2018b, 2020; Kosek, Čech, Navrátilová, Mačutek 2018a, 2018b).
Tato studie se zaměřuje na popis slovosledu pronominálních enklitik mi, ti, si, ho, $m u$ ve vybraných knihách Starého a Nového zákona Bible kralické. Zaměřuje se hlavně na distribuci jednotlivých forem dvou konkurenčních pozic, tj. postiniciální pozice a pozice kontaktní. Př́spěvek se zaměřuje na nepostiniciální pozice enklitik v Bibli kralické, které jsou výrazně méně časté než postiniciální pozice a ve skutečnosti jsou variantami pozice kontaktní. V článku se pokoušíme určit, do jaké míry slovosled původních textů (latinského, možná hebrejského a řeckého) ovlivňuje pořadí slov v překladu, zejména méně časté enklitické pozice. Díváme se na Starý a Nový zákon jako samostatné a nezávislé texty, protože jsou založeny na různých jazycích.

\section{1. Úvod}

Hlavním cílem předkládané studie je prozkoumat slovosled pronominálních forem $m i, t i, s i, h o, m u$ ve Starém i Novém zákoně Bible kralické a zejména analyzovat, zda a př́padně do jaké míry se na jejich slovosledných klauzálních pozicích podílí vliv slovosledu předloh, s nimiž Kraličtí při překladu pracovali. ${ }^{2}$

Pronominální enklitika, která jsou v tomto př́spěvku podrobena analýze, představují z vývojového hlediska poměrně různorodou skupinu. $\mathrm{V}$ prvé řadě se jedná o starobylá zájmenné formy $m i, s i, t i,{ }^{3}$ která měla již od praslovanského období status enklitik tantum. Nicméně ze skupiny starobylých pronominálních enklitických forem $m i, t i, s i$ je $\mathrm{v}$ rámci této studie analyzováno pouze $m i$, a to $\mathrm{z}$ důvodu velmi prostého - v Bibli kralické podobně jako v textech 1. a 2. staročeské biblické redakce nebyly zaznamenány žádné doklady pro formy $t i$, si. Absence enklitika $s i \mathrm{v}$ textech $\mathrm{z}$ období starších vývojových etap češtiny není nikterak zarážející, místo enklitické formy je využívána její dvouslabičná př́ízvučná forma sobě, první doklady si se objevují velmi posporu teprve až od 2. pol. 15 století. O tomto fenoménu je poměrně obšírně pojednáno $\mathrm{v}$ sekundární literatuře $\mathrm{k}$ historickému vývoji češtiny (viz např. Gebauer 189, s. 527; Havránek 1928, s. 100; Vážný 1964, s. 121), naproti tomu o absenci formy $t i \mathrm{v}$ textech staročeských či

\footnotetext{
2 O otázce předloh Bible kralické bude podrobněji pojednáno níže.

${ }^{3}$ Podrobněji bylo o slovosledu starobylých dativních forem $m i, t i$, si pojednáno v příspěvku Kosek, Čech, Navrátilová 2018a.
} 
středněčeských dostupné sekundární zdroje mlčí. ${ }^{4}$ Jelikož jsme o absenci forem $t i, s i$ ve starších biblických překladech a o př́ičinách této absence psali detailně na jiných místech (viz např. Kosek, Čech, Navrátilová 2018a), v rámci předkládané studie se již o tomto jevu bliže nezmiňujeme.

Dalšími analyzovanými formami jsou pronominální enklitika ho, $m u$ vzniknuvší z původních dvouslabičných přízvučných forem jeho $>j h o>h o, j e m u>j m u>m u$ redukcí vokálu $-e-\mathrm{v}$ nepř́zvučné první slabice a následně zánikem iniciálního $j-.^{5}$

Přestože tedy v rámci analyzované skupiny můžeme vyčlenit $d e$ facto dvě relativně samostatné skupiny: 1 . starobylé enklitikon $m i$ na jedné straně, 2. nově vzniklé klitické formy $m u$, ho na straně druhé, pro všechny formy je společná jedna vlastnost, a to jejich nepř́ízvučnost (enklitičnost), stojí tak v opozici proti pronominálním formám sě, tě, které ve starších fázích vývoje češtiny ještě reflektují zbytky své původní př́zvučnosti. ${ }^{6}$

Náš výzkum v rámci této studie omezujeme pouze na pronominální formy stojící ve frázi určitého slovesného tvaru (verba finita - VF), př́pady enklitik ve frázi infinitivu, přechodníků, dějových adjektiv či substantiv ponecháváme stranou, ${ }^{7}$ obdobně jako analýzu klitických skupin.

${ }^{4}$ Nabízí se zde otázka, zda forma $t i$ nemůže být ukryta v redukované formě $t$ ', nicméně již dříve realizovaný výzkum v Bibli olomoucké (Kosek, Čech, Navrátilová 2018a) ukázal, že v jen velmi malém procentu dokladů má $t$ 'status zájmenné

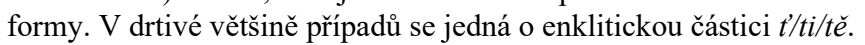

${ }^{5}$ Obecně se soudí, že tyto enklitické formy anaforického zájmena 3. osoby ho, $m u$ vznikly ještě v době před ustálením pevného slovního př́zvuku, tj. př́izvučná nebyla první, ale druhá slabika, tím pádem mohlo dojít k redukci vokálu (viz Gebauer 1896, s. 573-577; Vážný 1964, s. 124; Komárek 1981, s. 93).

${ }^{6}$ Detailní analýze slovosledného chování těchto forem jsme se věnovali na jiném místě Kosek, Čech, Navrátilová, Mačutek 2018d.

${ }^{7} \mathrm{~V}$ těchto př́padech se pronominální enklitika nacházejí v tzv. nekanonických pozicích, a jejich analýza tak vyžaduje zcela odlišný př́stup, který by již přesáhl rámec této studie (srov. Toman 2000, 2004; Kosek 2011, s. 32-33, s. 256-270).

\section{Jazykový materiál}

Analyzovaný pramen Bible kralická byla vydána v letech 1579 -1594 . Vznikla sice jakožto nový překlad z hebrejštiny a řečtiny, související se současnou evropskou humanistickou filologií a biblickou exegezí, avšak zároveň navazovala na předchozí českou biblistiku. Iniciátorem nového překladu byl moravský biskup Jednoty bratrské Jan Blahoslav (1523-1571), který ještě před zahájením vlastního překladu formuloval ve své Gramatice české stěžejní jazykové a stylistické zásady, jež lze hodnotit jako zcela klíčové pro výslednou kvalitu biblického překladu. Následně sám Jan Blahoslav přeložil Nový zákon, poprvé vydaný v roce 1564 , podruhé v roce 1568 . Úmyslu přeložit rovněž Starý zákon se již nedožil, v roce 1577 však na něj navázali učenci pod vedením Blahoslavova žáka Ondřeje Štefana. Překlad Starého zákona v 5 svazcích vycházel postupně mezi lety 1579-1588, $\mathrm{v}$ roce 1594 jej následovala zrevidovaná verze Blahoslavova Nového zákona (viz Kyas 1997, s. 185-6).

Přesné určení předloh, z nichž Blahoslav a jeho následovníci při překladu vycházeli, je poměrně nelehký úkol, který dodnes nebyl spolehlivě vyřrešen. Podle Vladimíra Kyase (1997, s. 190) je však především stěžejní nepokládat překlad Bible kralické za př́mou translaci z původních jazyků - hebrejštiny a řečtiny. Jde spíše o př́klon $k$ původní tradici biblického překladu místo nekritického přijímání podoby oficiální Vulgáty, kterým se vyznačovaly starší překlady zejména předchozího 15. století. Otázkou však i nadále zůstává poměr mezi prací s původními jazyky a prací za pomoci soudobých zahraničních překladů. Kyas v tomto ohledu vyzdvihuje zejména zkoumání Jaroslava Konopáska, jenž ve svých analýzách za hlavní předlohu Blahoslavova Nového zákona určil latinský text Theodora Bezy z roku 1559-1560 a rovněž Bezův řecký text z roku 1565 (viz Kyas 1997, s. 190-191). Pro pozdější revize NZ dokládá Kyas jako hlavní zdroj Bezovo řeckolatinské vydání z roku 1588-1589 (Kyas ibid.). ${ }^{8}$ Vedle toho měl na české znění Starého zákona zřejmě největší vliv latinský

\footnotetext{
${ }^{8}$ B1589. Více viz k tomuto tématu Dittmann 2012, s. 97-99.
} 
překlad Tremellia a Junia (1576-1579) ${ }^{9}$, který Kralickým posloužil nejen jako inspirace pro formální uspořádání jejich vydání, ale někdy také jako prŕmá předloha (srov. např. Kyas 1997, s. 191; Dittmann 2012, s. 373). O otázce vlivu Tremelliova-Juniova překladu na překlad Starého zákona Bible kralické jakožto i o dalších možných pretextech bylo již bohatě pojednáno $\mathrm{v}$ sekundární literatuře (podrobný soupis je možno nalézt v Dittmannově monografii (2012, s. 91-112).

Cílem tohoto př́spěvku ovšem není provést detailní komparaci znění reprezentovaného Bibli kralickou se všemi potenciálními předlohami, definovat slovosledné shody či diference $v$ rámci jednotlivých hebrejských/řeckých/latinských pretextů a následně určit vztahy mezi jednotlivými jazykovými verzemi i kralickým překladem. Naším hlavním záměrem je především zjistit, zda a nakolik se na slovosledu analyzovaných forem v Bibli kralické promítá vliv slovosledu cizojazyčného pretextu, a sice nezávisle na tom, zda se jedná konkrétně o vliv latiny, hebrejštiny či řečtiny. Navazujeme tak na již dř́ve realizovaný výzkum, v němž jsme zkoumali vliv latinské Vulgáty na slovosled pronominálních enklitik ve staročeské bibli první redakce (viz Kosek, Čech, Navrátilová 2020), který jednoznačně potvrdil, že slovosled cizojazyčného pretextu je jeden z významných faktorů podílejících se na distribuci konkurenčních slovosledných pozic pronominálních enklitik.

Vzhledem $\mathrm{k}$ poměrně velkému počtu potenciálních předloh, se kterými Kraličtí pracovali (či mohli pracovat), je oproti starším biblickým překladům situace v Bibli kralické poněkud komplikovaná. A to zejména $z$ toho důvodu, že řada potenciálních předloh je stále jen na úrovni hypotézy a dosud nebylo spolehlivě vyřešeno, zda a nakolik byly při překladu Kralické bible využívány (k tomu viz již výše zmíněný Dittmann 2012, s. 91-112). Z tohoto důvodu jsme se rozhodli zvolit vždy jeden hlavní pretext - pro Starý i Nový zákon - a to takový, který je sekundární literaturou obecně pokládán za dominant-

\footnotetext{
${ }^{9}$ O problematice datace prvního vydání překladu viz Dittmann 2012, s. 111.
}

ní. ${ }^{10} \mathrm{~V}$ př́ípadě Starého zákona tedy komparujeme jednotlivé doklady excerpované v Bibli kralické primárně s Tremelliovým-Juniovým latinským překladem ( $\mathrm{T}-\mathrm{J})$, v případě Nového zákona s Bezovým paralelním řecko-latinským překladem. Přestože sekundární literaturou je Tremelliův-Juniův latinský překlad vnímán jakožto velmi důležitý zdrojový text pro Kralické, je rovněž všeobecně dobře znám fakt, že Kraličtí při překladu Starého zákona pracovali s některými texty hebrejskými. Dlouhou dobu tradované tvrzení, že Bible kralická byla zcela novým překladem $\mathrm{z}$ původních jazyků, $\mathrm{z}$ hebrejštiny a řečtiny, bylo však zpochybněno (viz např. Kyas 1997, s. 190). Nicméně s výjimkou Polygloty antverpské (POLY), na kterou sami Kraličtí na několika místech upozorn̆ují, ${ }^{11}$ není zcela jasné, jaké další hebrejské edice mohli využívat. V samotných poznámkách Bible kralické je možno nalézt několik zmínek, které dokládají, že Kraličtí konzultovali více hebrejských textů. Otázka, o jaké texty se jednalo, však zatím zůstává nevyřešena (více k tomuto viz Dittmann 2012, s. 91-93). Abychom se tedy při naší analýze nedopouštěli zjednodušování (a to $v$ tom př́padě, že bychom zcela vypustili možnost vlivu hebrejského pretextu) a mohli tak lépe možný vliv slovosledu cizojazyčného pretextu prozkoumat, $v$ př́ípadech, kdy Tremelliův-Juniův latinský překlad reflektuje jiné znění proti Bibli kralické, či v něm zkoumaný element absentuje (a není tedy možné provést komparaci s latinským ekvivalentem), prrihlížíme rovněž k hebrejskému textu Polygloty antverpské (v př́ipadě Knihy Sirachovec k její řecké verzi). ${ }^{12}$

Tato skutečnost pak odráží i způsob zpracování a členění této studie - jelikož není možné (vzhledem k odlišným pretextům) realizovat současně výzkum Starého i Nového zákona, provádíme výzkum obou textů odděleně, nadto i s ohledem na povahu jednotlivých pre-

${ }^{10}$ Nabízela se samozřejmě i možnost srovnání překladu Bible kralické se všemi potenciálními předlohami, nicméně tento způsob zpracování by již přesáhl rámec našeho výzkumu.

${ }^{11}$ Rovněž Komenský v Historiole Polyglotu antverpskou hodnotí jako jednu ze dvou předloh Bible kralické (k tomu viz Dittmann 2012, s. 92).

${ }^{12}$ Jak sami Kraličtí v předmluvě k 5. svazku Bible kralické uvádějí, zdrojovým textem pro překlad Knihy Sírachovec jim byl řecký text Polygloty antverpské. 
textů (Starý zákon - dva odlišné jinojazyčné pretexty, Nový zákon jediný, paralelní bilingvní pretext) má analýza $\mathrm{v}$ rámci obou Zákonů trochu jiný způsob realizace.

Pokud jde o konkrétní výběr textů v rámci Starého i Nového zákona, volíme převážně ty knihy, které jsou pokud možno co nejvíce žánrově diferencovány - výběr tedy zahrnuje texty narativní, reflexivní, meditativní či mudroslovné apod.; předpokládáme totiž, že tato „větší žánrová pestrost" by se mohla pozitivně promítnout $\mathrm{v}$ jisté variabilitě slovosledného chování analyzovaných forem. Z Nového zákona jsme tedy analyzovali: Matoušovo (Mt) a Lukášovo (Lk) evangelium, Skutky apoštolů (Sk), Zjevení sv. Jana (Zj), ze Starého zákona je výzkumu podrobena kniha Genesis $(\mathrm{Gn})$, Job (Jb), Sírachovec (Sir) a Prorok Izajáš (Iz). Jednotlivé doklady excerpované v těchto knihách transkribujeme podle originálu, a to podle zásad, které pro moderní edici definoval R. Dittmann (2014, s. 21-31) - např. je ponechávána původn interpunkce (s výjimkou dvojí podoby čárky, kterou sjednocujeme na podobu commy), kvantita, geminované souhlásky, majuskule a grafická podoba slov cizího původu.

\section{Analýza}

Jak již ukázaly předchozí výzkumy starších biblí (Kosek, Čech, Navrátilová 2018a, 2018b; Kosek, Čech, Navrátilová, Mačutek 2018a, $2018 b$ - zde také viz př́íklady $\mathrm{k}$ níže uvedenému), všechny v této studii analyzované formy se vyznačují vlastnostmi stálých enklitik, tj. ř́dí se distribučními omezeními pro enklitika typickými: 1 . nemohou být modifikovány či koordinovány, 2 . neobjevují se po předložce, 3 . neobsazují iniciální pozici klauze, 4. nenásledují po citoslovci, 5. nenásledují po vokativu, 6 . nenásledují po konjunktorech $a$, ale, $i$. Jejich dominantní pozicí v klauzi je pozice postiniciální (neboli také druhá větná pozice; $2 \mathrm{P}$ ), kterou - jak je patrno z níže uvedené tabulky (tabulka 1) - zaujímají v drtivé většině případů. ${ }^{13}$ Tuto slovoslednou pozici demonstruje doklad 1 :

${ }^{13}$ Některé príipady postiniciálních pozic jsou však ambigní a při popisu slovosledného chování pronominálních enklitik v postiniciální pozici je vhodné tyto do-
[1]

A aj zavzněl hlas s nebe řkoucí, Totot' jest ten můj milý Syn, v němž mi se dobře zalíbilo. BiblKral Mt 3,17

Vedle toho však enklitika mohou obsazovat jinou než postiniciální pozici, a to uprostřed nebo na konci klauze. V drtivé většině př́padů jsou tyto pozice motivovány k ontaktním slovosledem, tj. pravidlem nutícím enklitika obsazovat pozice v bezprostřední blízkosti svého řídícího VF (který označujeme termínem regent enklitika). V historické češtině jsou dosvědčeny pozice enklitika jak před svým regentem (pozice preverbální - viz doklad 2), tak za ním (pozice postverbální - viz doklad 3). Je-li enklitikon umístěno uprostřed klauze, klasifikujeme toto postavení jako me di áln í (viz doklady 2 a 3). Je-li umístěno na předposlední pozici v klauzi za svým regentem, klasifikujeme tuto pozici jako pre finální (doklad 4). Je-li umístěno na úplný konec klauze za svým regentem, klasifikujeme tuto pozici jako fínáln í (viz doklad 5). Ve zcela ojedinělých dokladech může enklitikon zaujímat pozici m e diáln í i zo lova n o u, tj. pozici hlouběji v klauzi bez kontaktu se svým regentem (viz doklad 6).

[Že] [tak] mi učinil Pán ve dnech v nichžto vzezřel, aby odjal mé pohanění mezi lidmi. BiblKral Lk 1,25

[3]

I stalo se když k smrti pracovala, (nebo umřela,) nazvala jméno jeho Ben Ony: ale [otec jeho] nazval ho Benyaminem. BiblKral Gn 35,18

[4]

[Poněvadž] [tedy] [David] [Pánem] ho nazývá, i kterakž syn jeho jest? BiblKral Mt 22,45

klady z analýzy vyloučit. Jedná se o takové případy, v nichž enklitikon je ve druhé větné pozici, ale současně v pozici kontaktní, nebot' jeho rídící sloveso bud' zaujímá v klauzi iniciální větnou pozici a enklitikon pak stojí v pozici postiniciální, postverbální, nebo sloveso následuje až po enklitiku a to pak zaujímá pozici postiniciáln a současně preverbální. Na tuto skutečnost jsme už upozornili na jiném místě (Kosek, Čech, Navrátilová, Horák 2020)

${ }^{14} \mathrm{~V}$ tomto př́padu se jedná o doklad klitické skupiny mi se. 
[5]

A odpověděli sme pánu mému; Máme otce, starého, a pachole v starosti jeho zplozené malé, jehož bratr umřel, a on sám zůstal po mateři své, a [otec jeho] miluje ho. BiblKral Gn 44,20

[6]

[Jakož] i [Biskup] svědek mi toho jest, i všickni Starší [...] BiblKral Sk 22,5

Tabulka 1. Frekvence jednotlivých klauzálních pozic analyzovaných forem

\begin{tabular}{|c|c|c|c|c|c|c||}
\hline $\begin{array}{c}\text { pronomi- } \\
\text { nální for- } \\
\text { ma/pozice }\end{array}$ & iniciální & postiniciální & mediální & prefinální & finální & $\Sigma$ \\
\hline$m i$ & 0 & 260 & 34 & 4 & 14 & 312 \\
\hline$s i$ & 0 & 0 & 0 & 0 & 0 & 0 \\
\hline$t i$ & 0 & 0 & 0 & 0 & 0 & 0 \\
\hline$h o$ & 0 & 300 & 22 & 6 & 35 & 363 \\
\hline$m u$ & 0 & 184 & 21 & 0 & 14 & 219 \\
\hline$\Sigma$ & 0 & 744 & 77 & 10 & 63 & 894 \\
\hline
\end{tabular}

Frekvence klauzálních pozic a frekvence pozic enklitika vůči VF $\mathrm{v}$ rámci jednotlivých analyzovaných biblických knih zachycují níže uvedené tabulky č. 2 a 3 . V těchto tabulkách jsme se rozhodli frekvence jednotlivých enklitik sloučit, protože jednotlivě se zpravidla vyskytují ve statisticky málo významném počtu.

Tabulka 2. Frekvence jednotlivých klauzálních pozic zkoumaných forem v analyzovaných knihách

\begin{tabular}{|c|c|c|c|c|c|c|}
\hline & iniciální & postiniciální & mediální & prefinální & finální & $\Sigma$ \\
\hline $\mathrm{Gn}$ & 0 & 241 & 34 & 5 & 26 & 306 \\
\hline$\%$ & $0 \%$ & $78,80 \%$ & $11,11 \%$ & $1,63 \%$ & $8,46 \%$ & \\
\hline $\mathrm{Jb}$ & 0 & 92 & 9 & 1 & 5 & 107 \\
\hline$\%$ & $0 \%$ & $86 \%$ & $8,40 \%$ & $0,90 \%$ & $4,70 \%$ & \\
\hline $\mathrm{Sir}$ & 0 & 56 & 5 & 1 & 3 & 65 \\
\hline$\%$ & $0 \%$ & $86,20 \%$ & $7,70 \%$ & $1,50 \%$ & $4,60 \%$ & \\
\hline $\mathrm{Iz}$ & 0 & 44 & 7 & 1 & 4 & 56 \\
\hline$\%$ & $0 \%$ & $78,60 \%$ & $12,50 \%$ & $1,80 \%$ & $7,10 \%$ & \\
\hline $\mathrm{Mt}$ & 0 & 107 & 10 & 1 & 7 & 125 \\
\hline
\end{tabular}

\begin{tabular}{||c|c|c|c|c|c|c||}
\hline \hline$\%$ & $0 \%$ & $85,60 \%$ & $8 \%$ & $0,80 \%$ & $5,60 \%$ & \\
\hline $\mathrm{Lk}$ & 0 & 101 & 6 & 1 & 13 & 121 \\
\hline$\%$ & $0 \%$ & $83,50 \%$ & $5 \%$ & $0,80 \%$ & $10,70 \%$ & \\
\hline $\mathrm{Sk}$ & 0 & 77 & 6 & 0 & 3 & 86 \\
\hline$\%$ & $0 \%$ & $89,50 \%$ & $7 \%$ & $0 \%$ & $3,50 \%$ & \\
\hline $\mathrm{Zj}$ & 0 & 26 & 0 & 0 & 2 & 28 \\
\hline$\%$ & $0 \%$ & $92,90 \%$ & $0 \%$ & $0 \%$ & $7,10 \%$ & \\
\hline$\Sigma$ & 0 & 744 & 77 & 10 & 63 & 894 \\
\hline
\end{tabular}

Tabulka 3. Pozice $m i$, ho, $m u$ vůči řídícímu slovesnému tvaru $\mathrm{v}$ analyzovaných

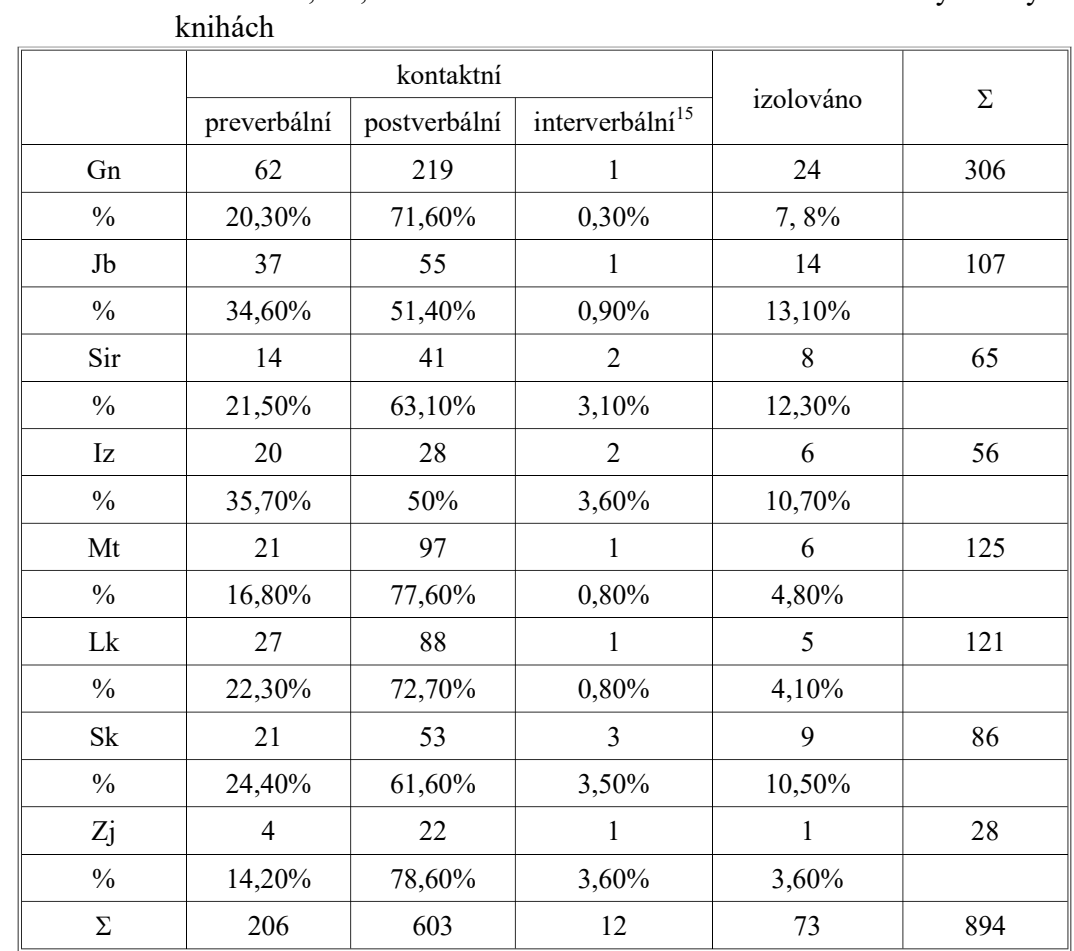

15 Jedná se o pozici enklitika, jehož ř́ícícím výrazem je analytická slovesná forma a enklitikon zaujímá pozici mezi jednotlivými složkami tohoto výrazy, tj. typ bude mi psát. 
Nepostiniciální pozice ${ }^{16}$ představují konkurenční vývojový model pozice postiniciální a jejich využití, jak ukázaly dosavadní výzkumy (Kosek, Čech, Navrátilová 2018a, 2018b; Kosek, Čech, Navrátilová, Mačutek 2018a, 2018b), je motivováno ve starších českých textech různými faktory: sty lem, prozodií, k omplexitou fráze či slovosledem pretextu. V našem př́spěvku bude pozornost věnována poslednímu jmenovanému faktoru, tj. zaměřujeme se na otázku, jakou měrou se podílí slovosled předlohy (latiny, ev. hebrejštiny a řečtiny) na umístění enklitika do nepostiniciální kontaktní pozice. $\mathrm{O}$ vlivu ostatních faktorů jsme již podrobněji pojednávali na jiných místech, proto se jimi v této studii již dále nezabýváme (Kosek, Čech, Navrátilová 2018a, 2018b; Kosek, Čech, Navrátilová, Mačutek 2018a, 2018b Kosek, Čech, Navrátilová, Horák 2020).

Primárně je tedy tato studie věnována př́ípadům nepostiniciálních pozic, které jsou doloženy pro jednotlivé analyzované formy. ${ }^{17} \mathrm{Aby}-$ chom však mohli lépe postihnout míru skutečného vlivu slovosledu pretextu $\mathrm{v}$ tomto parametru, je potřeba podívat se rovněž na př́ípady pozic postiniciálních a ověřit, do jaké míry se $\mathrm{v}$ rámci této pozice uplatňuje vliv linearizace cizojazyčné předlohy, a na základě toho pak definovat, zda je vliv pretextu specifický právě pro umístění enklitik do pozic nepostiniciálních ( $\mathrm{tj}$. potvrdit významnost tohoto faktoru v rámci výskytu nepostiniciálních pozic), nebo se naopak uplatňuje poměrně konstantní míra vlivu pretextu na slovosled pronominálních forem nezávisle na jejich pozici (postiniciální vs. kontaktní). Z výše uvedeného důvodu (a stejně tak $z$ důvodů rozsahových) pro srovnání dokládáme i sondou omezenou analýzu pozic postiniciálních, přičemž rozsah sondy je definován počtem prvních 15 dokladů $\mathrm{z}$ každé biblické knihy pro každou pronominální formu. ${ }^{18}$

${ }^{16} \mathrm{Z}$ předchozího výkladu plyne, že tímto způsobem souborně označujeme všechny př́pady klauzálních pozic mimo pozici postiniciální.

${ }^{17}$ Jak již bylo řečeno, vzhledem k velmi nízkému počtu dokladů pro jednotlivé pronominální formy jsme nuceni ve většině př́ípadů prezentovat výsledky pro všechny analyzované zájmenné formy souhrnně.

${ }^{18} \mathrm{Ne}$ vždy je ovšem možno tento rozsah dodržet, nebot' v některých biblických knihách není možné doložit pro všechny pronominální formy oněch 15 dokladů,

\subsection{Starý zákon}

Jak již bylo zmíněno výše, $v$ rámci analýzy Starého zákona jsme primárně český text komparovali s latinským překladem Tremelliovým-Juniovým, konkrétně s jeho 1 . vydáním. V př́padě, že jsme zachytili shodu v klauzální pozici i shodu v pozici vǐči VF (viz doklad 7), již jsme český text nesrovnávali s Polyglotou antverpskou a chápali jsme uvedené doklady jako př́ípady vlivu cizojazyčného pretextu na slovosled pronominálních forem; celkem jsme zachytili 67 dokladů tohoto typu:

[7a]

I řekl Adam; Žena, kterouž si dal, aby byla se mnou, [ona] dala mi z stromu toho, a jedl sem. BiblKral Gn 3,12

[7b]

Tunc dixit Adam, mulier ista quam collocasti mecum [ipsa] dedit mihi de fructu illius arboris, \& comedi. T-J BiblKral Gn 3,12.

$\mathrm{V}$ případě, že se slovosled pronominální formy v Bibli kralické neshodoval se slovosledem latinského zájmena, a to $\mathrm{v}$ pozici vůči slovesu a/nebo v klauzální pozici, srovnávali jsme dále se zněním Polygloty (celkem se jednalo o 34 takových dokladů), abychom v př́padě absence vlivu latinského pretextu zjistili, zda se zde neuplatňuje vliv pretextu hebrejského (v př́ípadě Sir řeckého). Celkově jsme identifikovali 9 takových případů, kdy se slovosled pronominální formy neshodoval se slovosledem latinského zájmena, ale shodoval se se slovosledem hebrejského zájmena - viz např. níže uvedený doklad $8^{19}$ :

[8a]

Jméno pak druhého nazval; Efraim, řka; [Nebo] dal mi Bůh zrůst v zemi trápení mého. BiblKral Gn 41,52

z toho důvodu je pak v níže uvedených grafech celkový počet dokladů nižší, než by se dalo očekávat.

${ }^{19} \mathrm{~V}$ prípadě řeckého pretextu Knihy Sírachovec nebyl doložen žádný takový př́pad. 
[8b]

Nomen autem secundi vocavit Ephrajimum, [quia] me, inquit, fructuosum reddidit Deus in terra afflictionis meae. (T-J) BiblKral Gn 41,52

[8c]

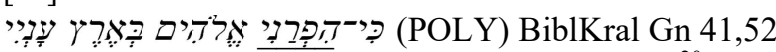

protože rozplodil-mne Bůh $\mathrm{v}$ zemi trápení mého ${ }^{20}$

Tyto př́ípady, kdy slovosledná pozice českého enklitika neodpovídá slovosledné pozici latinského pretextu, nýbrž slovosledné pozici hebrejského pretextu, nejsou v analyzovaném souboru dokladů př́liliš frekventované (jedná se o 9 dokladů z celkových 25 př́ípadů). Vedle toho jsme zaznamenali 16 prŕípadů, kdy se slovosled českého zájmena neshodoval ani se slovosledem hebrejského a ani řeckého zájmena to demonstrují např́klad doklady 9,10 . Je tedy otázkou, zda se zde uplatňují faktory jiné povahy (prosodie, styl apod.), či jsou tyto př́ípady svědectvím vlivu starší české překladatelské tradice. ${ }^{21}$ Výzkum v tomto směru by však již značně přesahoval rámec této studie, proto se jím zde dále nezabýváme. Stejně tak poznámkou v rámci našeho zkoumání spíše marginální je, že v 15 prrípadech z celkových 16 excerpovaných dokladů tohoto typu se prritom shodovala slovosledná pozice latinského a hebrejského/řreckého zájmena. Tento stav zachycuje např́klad zmíněný doklad $10 \mathrm{~b}$ a $10 \mathrm{c}$ :

[9a]

Nemůžet' hněvivý člověk spravedliv býti, [nebo] [prudkost hnevu jeho] bývá mu ku pádu. BiblKral Sir 1,22

[9b]

Non potest iracundus quisquam justificari; nam momentum iracundiae ejus est ruinae ipsi. (T-J) BiblKral Sir 1,22

${ }^{20}$ Každý hebrejský doklad opatřujeme českým překladem, který má zejména ilustrovat pozici pronominální formy v hebrejské klauzi. Formy, které se chovají jako flektivní sufixy a které jsou součástí slovesné formy, signalizujeme spojovníkem.

${ }^{21}$ Ani otázka vlivu starších biblických překladů není dosud spolehlivě vyřešena. Jako možné předlohy Kralické bible bývají uváděny nejstarší tištěné bible (Bible pražská, Kutnohorská a Benátská) či Bible Melantrichova (k této problematice více viz Dittmann 2012, s. 146-149). [9c]

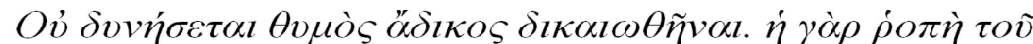

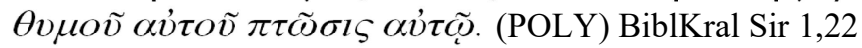

[10a]

Měl pak Jozef sen, a vypravoval jej bratřím svým: [pročež] [v větší nenávisti] ho měli. BiblKral Gn 37,5

[10b]

Praeterea cum somniasset Joseph somnium, narrabat illud fratribus suis: quamobrem magis adhuc oderant eum. (T-J) BiblKral Gn 37,5

[10c]

(POLY) BiblKral Gn 37,5

a-přidali ještě nenávidět-ho.

Komparaci s Polyglotou jsme rovněž realizovali v případě, že v latinském pretextu scházel odpovídající element a možnost vlivu latinského zájmena byla z toho důvodu vyloučena. V 5 př́ípadech z celkových 9 dokladů tohoto typu jsme zaznamenali shodu kralického znění s Polyglotou - viz např. doklad 11:

[11a]

[Tedy] vypravovali mu všecka slova Jozefova, kteráž mluvil jim: BiblKral Gn 45,27

[11b]

Sed cum elocuti essent omnia verba Josephi quibus erat allocutus eos. (T-J) BiblKral Gn 45,27

[11c]

(POLY) BiblKral Gn 45,27

A-pověděli $(\mathrm{k})$ - $\underline{\mathrm{mu}}$ všechna slova Josefova

Vedle toho $\mathrm{v}$ dalších 3 případech nebyl odpovídající element zaznamenán ani v Polyglotě a ani v T-J, jak demonstruje doklad 12a-c:

Pozůstalí po něm v smrti pohřbeni budou, a [vdovy jeho] nebudou ho plakati. BiblKral Job 27,15 
[12b]

Superstites ejus in ipsa morte sepeliuntur \&; viduae ejus non flent. (T-J) BiblKral Job 27,15

\section{[12c]}

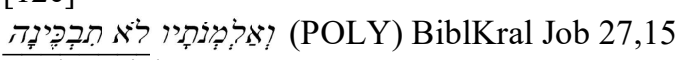

a-vdovy-jeho nebudou.plakat.

Jednotlivé případy vztahu mezi slovosledem kralickým, latinským a hebrejským ilustruje následující graf 1.

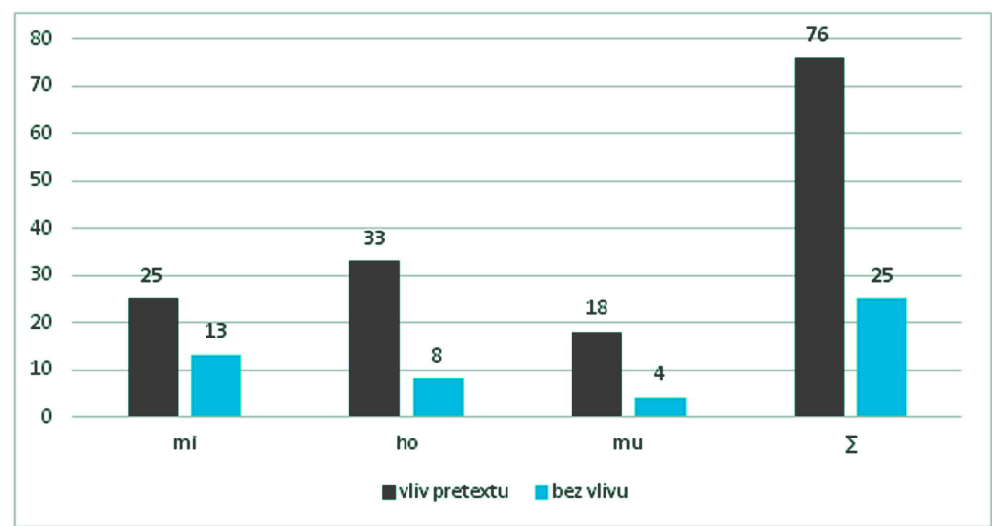

Graf 1. SZ Vliv pretextu na slovosled $m i, h o, m u$-nepostiniciální pozice

Jak je z uvedeného grafu patrno, vliv pretextu na umístění pronominálních forem $m i, h o, m u$ do nepostiniciálních pozic je evidentní, a to v cca $75 \%$ všech dokladů. Situace je pro všechny analyzované formy de facto velmi podobná, pouze pro formu mi je zaznamenán vliv nepatrně slabší (cca 65,8 \%; pro ho 80,5\% dokladů; pro $m u$ $81,9 \%$ ). Z celkového počtu vyexcerpovaných dokladů ve 25 prŕpadech není možno vliv žádné ze zkoumaných cizojazyčných předloh na umístění zájmen do nepostiniciálních pozic zaznamenat. Je tedy otázkou, nakolik zde vstupují do hry další faktory, jako např. prozodické faktory, stylotvorné faktory, komplexita fráze apod. (srov. Kosek, Čech, Navrátilová, Horák 2020).
Pokud se pro srovnání blíže podíváme na situaci v pozici postiniciální, je zřejmé, že v tomto př́ipadě je vliv pretextů rapidně slabší: jedná se o cca 29,5 \% dokladů pro všechny formy souhrnně (viz např́klad doklady 13,14$)$. Ve většině případů slovosled českého zájmena neodpovídá ani latinskému, ani hebrejskému pretextu, přičemž diference mohou být rovněž způsobeny odlišným slovosledem kralického znění a pretextu viz doklady 15c, 16b-c či absencí daného cizojazyčného ekvivalentu ve zkoumaných pretextech (doklad 15b).

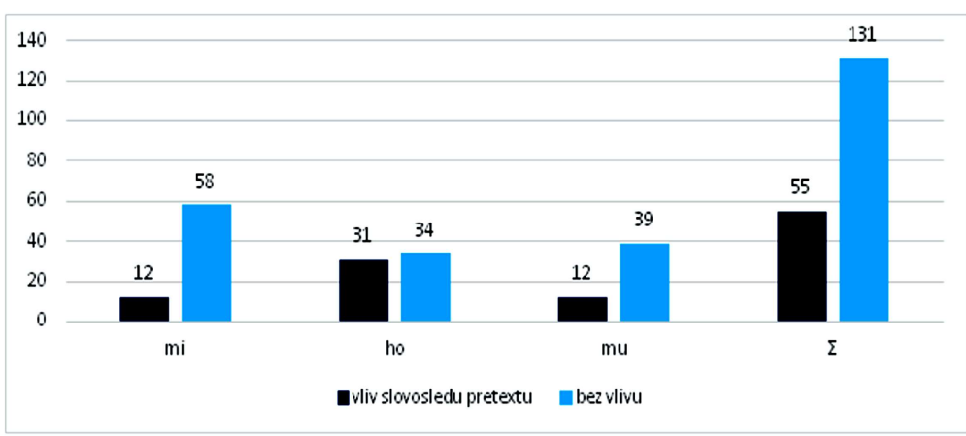

Graf 2. SZ Vliv pretextu na slovosled $m i, h o, m u$ - postiniciální pozice

[13a]

Král pak Sodomský řekl k Abramovi; Dej mi lid, a zboží vezmi sobě. BiblKral Gn 14,21

[13b]

Qua propter dixit Rex Sedomi ad Abramum, da mihi animas, facultates vero accipe tibi. (T-J) BiblKral Gn 14,21

[13c]

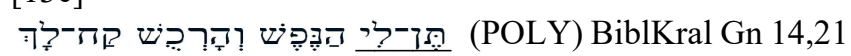

Dej mi duši a majetek vezmi si.

[14a]

I odpověděl mu; Vezmi mi jalovici tř́letou, a kozu tříletou, a skopce trŕiletého, hrdličku také a holoubátko. BiblKral Gn 15,9 
[14b]

Edixerat ei, sume mihi vitulam triennem, \& capram triennem, \& arietem triennem, turturemque \& pullum columbarum.

[14c]

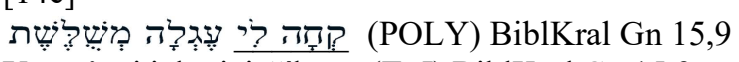

Vezmi mi jalovici tř́letou (T-J) BiblKral Gn 15,9

[15a]

Ale o ovoci stromu, kterýž jest v prostřed Ráje, řekl Bůh; Nebudete ho jísti, aniž se ho dotknete, abyšte nezemřeli. BiblKral Gn 3,3

\section{[15b]}

At de fructu arboris istius quae est in medio horti, dixit Deus, ne comedatis, nempe ex isto, neque attingatis eum, ne moriamini. (T-J) BiblKral Gn 3,3

\section{[15c]}

\section{(POLY) BiblKral Gn 3,3}

ne/budete. jíst Z-něho

\section{[16a]}

I učinil Noé podlé všeho jakž mu rozkázal Bůh, tak učinil. BiblKral, Gn 6,22

\section{[16b]}

Quod fecit Noach: secundum omnia quae praeceperat ei Deus, sic fecit. (T-J) BiblKral, Gn 6,22

[16c]

(POLY) BiblKral, Gn 6,22

A-učinil Noach podle-všeho, čím pověřil ho Bůh

\subsubsection{Shrnutí}

Většina zjištěných dokladů nepostiniciálních pozic sledovaných pronominálních enklitik ve Starém zákoně Bible kralické kopíruje slovoslednou pozici svého cizojazyčného ekvivalentu $\mathrm{v}$ analyzovaných pretextech (více než dvě třetiny). I když pracujeme s nízkým počtem analyzovaných forem, a tudíž nejsou naše výsledky statisticky významné, přesto můžeme předpokládat, že je to důsledkem vlivu předlohy. Nicméně tento vliv pretextů na slovosled českých enklitik není systematický, protože pozice postiniciální odpovídají slovosledným pozicím předloh v mnohem menším procentu dokladů (méně než jedna třetina dokladů).

\subsection{Nový zákon}

Jak jsme již zmínili výše, situace v Novém zákoně je, co se týče vztahu k pretextům, poněkud odlišná. Vzhledem k tomu, že Bezův překlad reprezentuje řecko-latinské znění biblického textu, srovnávali jsme doklady excerpované $\mathrm{v}$ Bibli kralické $\mathrm{s}$ celým pretextem, tj. latinským i řeckým překladem. $V$ rámci pozic nepostiniciálních jsme tedy provedli detailní komparaci všech řeckých i latinských dokladů ${ }^{22}$ a pro srovnání se zjištěným stavem (obdobně jako ve Starém zákoně) rovněž realizovali sondu o rozsahu 15 prvních dokladů z každé analyzované biblické knihy pro každou pronominální formu. ${ }^{23}$

Celkem jsme definovali 3 typy, $v$ jejichž rámci je možno počítat s vlivem pretextu: 1. klauzální pozice českého zájmena (včetně jeho pozice vưči regentu) je totožná ve všech 3 analyzovaných textech (viz doklad 17) - celkem zjištěno 30 takových př́padů; 2. klauzální pozice českého zájmena (včetně pozice vůči regentu) je identická v latinském pretextu, ale liší se v pretextu řeckém či v něm schází (viz doklady 18 , 19) - celkem identifikovány 4 doklady tohoto typu; 3 . klauzální pozice českého zájmena (včetně jeho pozice vưči regentu) je shodná $\mathrm{s}$ řeckým pretextem, ale liší se v pretextu latinském (viz doklad 20) ${ }^{24}$ celkem zaznamenány 2 doklady. $V 11$ př́padech nebyl zachycen žádný vliv pretextu, a to $\mathrm{z}$ důvodu absence daného ekvivalentu v cizojazyčném pretextu či vlivem jeho odlišného slovosledu (opět marginální

${ }^{22}$ Podobně jako ve Starém zákoně nás ovšem s ohledem na téma nezajímá vztah mezi latinským a řeckým překladem, ale pouze vztah mezi kralickým a řeckým/latinským textem.

${ }^{23}$ I zde platí to, co bylo již uvedeno výše, ne v každé biblické knize je možno nalézt požadovaný počet dokladů pro každou analyzovanou formu, $\mathrm{z}$ toho důvodu je tedy celkový počet dokladů nižší, než by se dalo očekávat.

${ }^{24}$ Př́ípady s absencí latinského a současně s př́ítomností řeckého zájmena nejsou $\mathrm{v}$ analýze doloženy. 
poznámkou je, že v 9 př́padech z celkových 11 se shodoval latinský a řecký pretext).

[17a]

[Opět] pojal ho d'ábel na hưru vysokou velmi, a ukázal mu všecka království světa, i slávu jejich [...] BiblKral Mt 4,8

[17b]

[Rursum] assumit eum diabolus in montem sublimem valde, \& ostendit ei omnia regna mundi, \& gloriam eorum [...] (B1588-L) BiblKral Mt 4,8

[17c]

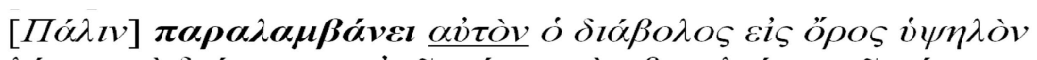

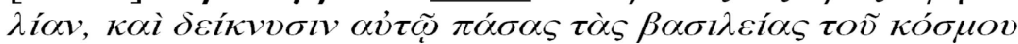

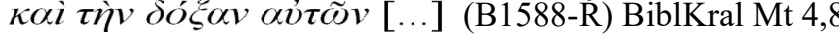

[18a]

Dí jim, [Kterakž] pak [David] [v Duchu] nazývá ho Pánem, řka, BiblKral Mt 22,43

[18b]

Dicit eis, [Quomodo] ergo [David] [per Spiritum] vocat eum dominum? Dicens... (B1588-L) BiblKral Mt 22,4

\section{$[18 \mathrm{c}]$}

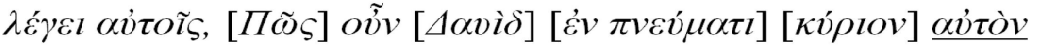

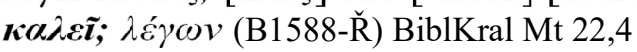

[19a]

[Ti] pak kteříž provodili Pavla, dovedli ho až do Atén: a vzavše poručení k Sílovi a k Tymoteovi, aby přišli k němu což nejspíše mohou, šli zase. BiblKral Sk 17,15

[19b]

[Qui] vero Paulum susceperant tuto loco constituendum, deduxerunt eum Athenas usque: \& accepto mandato ad Silam ac Timotheum, ut quam citissime ad ipsum venirent, abierunt. (B1588-L) BiblKral Sk 17,15

\section{[19c]}

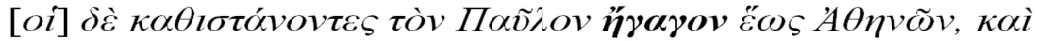

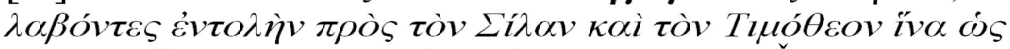

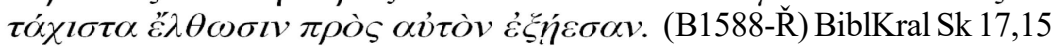

[20a]

A optal-lit' by se vás kdo, Proč je odvazujete? tak jemu díte, [Proto že] [Pán] ho potřebuje. BiblKral Lk 19,31

[20b]

Et si quis vos interrogaverit, Quare soluitis? Sic dicetis, ei, Quoniam eo opus est Domino. (B1588-L) BiblKral Lk 19,31

[20c]

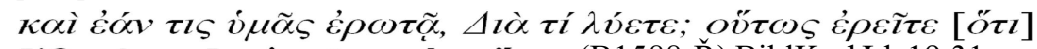

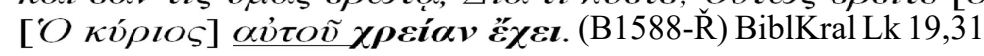

Pokud jde o poměr shod a rozdílů ve slovosledné pozici českého zájmena s řeckým a latinským pretextem, situace je v Novém zákoně zcela identická se situací ve Starém zákoně: souhrnně jsme zjistili cca 75 \% shod (podrobněji graf 3 uvedený níže). Tato situace je ovšem doložena zejména pro zájmenné formy ho $(81,8 \%)$ a $m u(84,6 \%)$ - viz doklady 17, 18, 19a, b, 20, 21, pro mi je stav poněkud rozkolísaný (58,8 \% pŕípadů shody ku 41,2 \% rozdílu) - viz doklady 22,23 . Bez jakéhokoli vlivu pretextu bylo celkem zjištěno 13 dokladů. ${ }^{25}$

[21a]

[Tedy] dí mu Ježíšs, Odejdiž satane: nebot' jest psáno, Pánu Bohu svému klaněti se budeš, a jemu samému sloužiti budeš. BiblKral Mt 4,10

[21b]

[Tunc] dicit ei Iesus, Abi Satana. Scriptum est enim, Dominum Deum tuum adorabis, \& ei soli servies. (B1588-L) BiblKral Mt 4,10

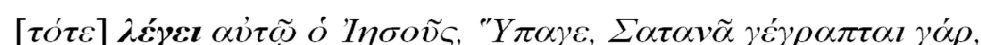

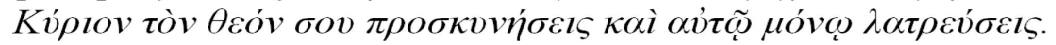
(B1588-ॅ̌) BiblKral Mt 4,10

${ }^{25}$ Těchto 13 dokladů jsme srovnali s Blahoslavovým druhým, revidovaným vydáním Nového zákona 1568, o němž je známo, že obdobně jako pozdější verze z roku 1582, 1588, vydané po Blahoslavově smrti (viz Kyas 1997, s. 195), sloužil jako hlavní zdrojový text pro znění Nového zákona Bible kralické. Ve 12 př́padech z 13 se slovosled sledovaných forem shodoval se zněním v NZ 1568! Je tedy evi- 
[22a]

[Že] [tak] mi učinil Pán ve dnech v nichžto vzezřel, aby odjal mé pohanění mezi lidmi. BiblKral Lk 1,25

[22b]

[Nempe] [ita] mihi fecit Dominus diebus quibus me intuitus est, ut auferret probrum illud meum inter homines. (B1588-L) BiblKral Lk 1,25

[22c]

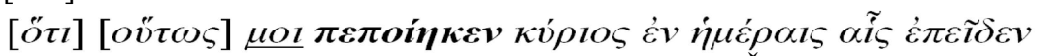

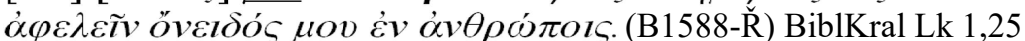

\section{[23a]}

A on odpověděv, řekl Otci, Aj tolik let sloužím tobě: a nikdý sem přikázaní tvého nepřestoupil: [a však] [nikdý] si mi nedal ani kozelce, abych také s přáteli svými vesel pobyl. BiblKral Lk 15,29

\section{[23b]}

Ipse vero respondens dixit patri, Ecce, tot annos servio tibi, nec unquam mandatum tuum sum transgressus, [nec] [unquam] dedisti mihi hoedum, ut cum amicis meis oblectarer. (B1588-L) BiblKral Lk 15,29

\section{[23c]}

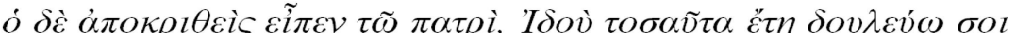

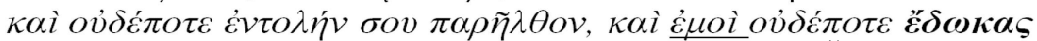

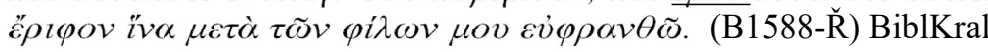
Lk 15,29.

Pokud se blíže podíváme na výsledky výzkumu vztahu postiniciální pozice pronominálních enklitik a zkoumaných pretextů v Novém zákoně, pozorujeme, že na rozdíl od Starého zákona je i zde vliv pretextu poměrně silný. Jak ukazuje graf graf 4 , cca $64,3 \%$ všech př́ípadů se shoduje. $Z$ tohoto grafu je rovněž patrno, že míra vlivu je velmi podobná pro všechna zájmena, nejsilnější pro ho (mi: 61,6 \%, ho: $70,1 \%, m u: 60 \%$ ).

dentní, že na linearizaci sledovaných zájmenných forem v Bibli kralické měla vli i předchozí překladatelská tradice, pro nedostatek místa se touto otázkou zde již dále nezabýváme.

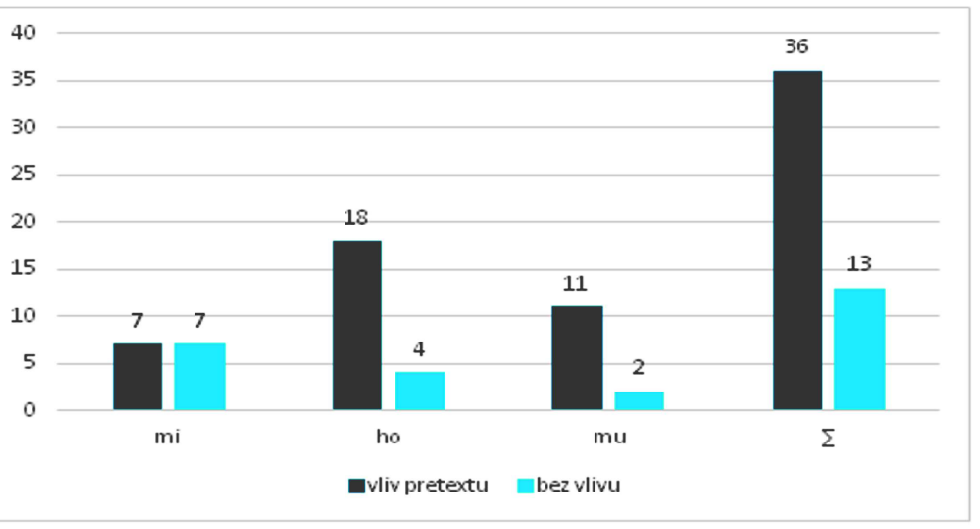

Graf 3. NZ Vliv pretextu na slovosled $m i, h o, m u$ - nepostiniciální pozice

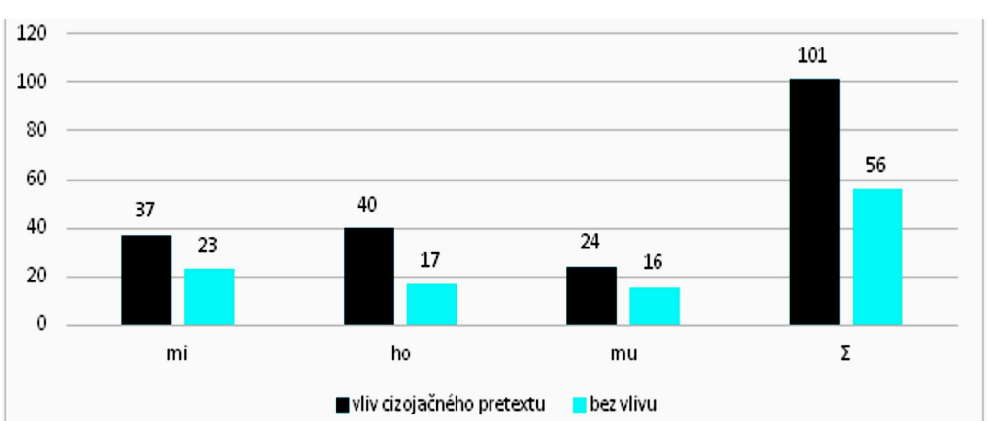

Graf 4. NZ Vliv pretextu na slovosled $m i, h o, m u$ - postiniciální pozice

Shodnou postiniciální pozici pronominálních enklitik a řeckého a latinského pretextu ilustrují doklady $24 \mathrm{a}-\mathrm{c}, 25 \mathrm{a}-\mathrm{c}$.

[24a]

I řekl mu Petr, Eneáši, uzdravujet' tebe Ježíš Krystus, vstaň, a ustel sobě: A hned vstal. Biblkral, Sk 9,34

[24b]

Et dixit ei Petrus, Aenea, sanat te Iesus Christus: surge, \& sterne tibi ipsi. Is autem statim surrexit. 
[24c]

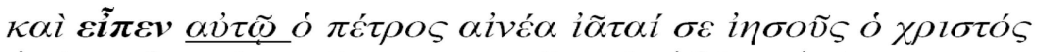

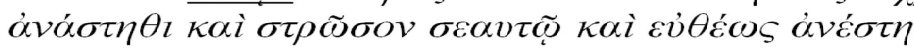

[25a]

Jiný pak z učedlníků jeho řekl jemu, Pane, dopust' mi prve odjíti, a pochovati otce mého. BiblKral Mt 8,21

\section{[25b]}

Alius autem ex discipulis eius dixit ei: Domine permitte mihi primum abire, \& sepelire patrem meum. (B1588-L) BiblKral Mt 8,21

\section{[25c]}

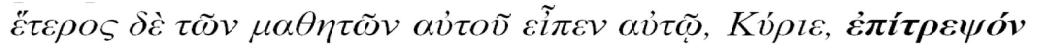

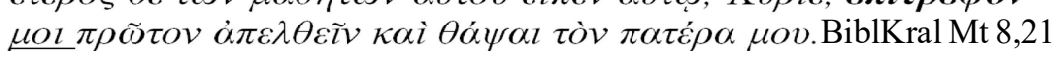

Tento výraznější vliv slovosledu pretextu u pozic postiniciálních by snad bylo možné přičíst tomu, že se $\mathrm{v}$ Novém zákoně (zejména v evangeliích) s poměrně vysokou frekvencí objevují ve všech zkoumaných textech (českém - latinském - řeckém) konstrukce s navazovací ćásticí $i$, přičemž $\mathrm{VF} v$ těchto př́padech bezprostředně následuje po této částici, tj. doklady typu A prosili ho - viz např́klad doklady 26 a 27:

[26a]

A prosili ho, aby se aspoň podolka roucha jeho dotkli: BiblKral Mt 14,36

[26b]

Et precabantur eum, ut solum tangerent fimbriam palii ipsius. (B1588-L) BiblKral Mt 14,36

[26c]

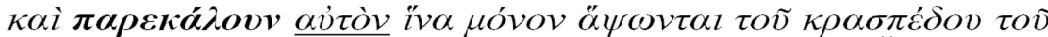

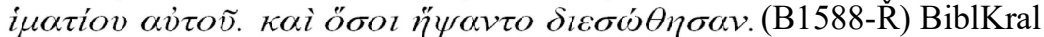
Mt 14,36

[27a]

A jakž byl den, vyšed bral se na pusté místo. I hledali ho zástupové, a přišli až k němu: a zdržovali ho aby neodcházel od nich. BiblKral Lk 4,42

\section{[27b]}

neruntque usque ad ipsum, \& retinebant eum ne ab ipsis disceret. (B1588-L) BiblKral Lk 4,42

\section{[27c]}

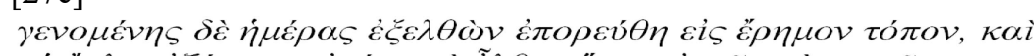

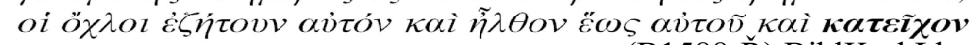

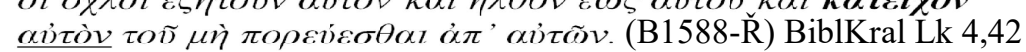

O pravidelném výskytu těchto konstrukcí v Bibli kralické píše již Š. Zikánová (2009, s. 178-179), která na základě tohoto pozorování usuzuje, že tyto konstrukce pravděpodobně mají výrazný podíl na frekventovanějším umístění VF v iniciální klauzální pozici. Je tedy zřejmé, že zde dochází k př́imému kopírování slovosledu ve směru cizojazyčný pretext (řrecký/latinský) $\rightarrow$ Bible kralická.

\subsubsection{Shrnutí}

I v rámci Nového zákona se potvrdilo, že umístění pronominálních forem do nepostiniciálních pozic je silně ovlivněno slovosledem pretextu. Nicméně jistou odlišnost (oproti Starému zákonu) je možno zaznamenat $\mathrm{z}$ hlediska vlivu pretextu $\mathrm{v}$ pozicích postiniciálních. Zatímco ve Starém zákoně byl zaznamenán v pozici postiniciální vliv jen velmi slabý, $v$ př́padě Nového zákona je možno zaznamenat poměrně stabilní vliv pretextu v pozicích postiniciálních i nepostiniciálních.

\section{Závěr}

Předložená studie se zabývala slovosledem pronominálních enklitik $m i, t i, s i, h o, m u$ ve vybraných knihách Starého i Nového zákona Bible kralické. (SZ: Genesis, Kniha Jób, Kniha Izajáš, Kniha Sírachovec; NZ: Evangelium podle Matouše, Evangelium podle Lukáše, Skutky apoštolů, Zjevení sv. Jana). Prvním důležitým zjištěním bylo, že ze skupiny starobylých praslovanských enklitik $m i, s i$, $t i$ zde absentují formy $t i$ a si (v tom se Bible kralické shoduje s jazykem staročeské bible 1. redakce). Dále jsme $\mathrm{v}$ rámci analýzy dospěli $\mathrm{k}$ závěru, že všechny zkoumané formy $m i, h o, m u$ se vyznačují vlastnostmi stálých 
enklitik. Poté jsme se zabývali otázkou, jakou měrou se podílí linearizace pretextu na distribuci postiniciálních a nepostiniciálních pozic těchto pronominálních forem. Výzkum jsme realizovali samostatně v rámci Nového i Starého zákona a na základě jeho výsledků jsme dospěli k závěru, že v př́ípadě nepostiniciálních pozic je situace z hlediska uplatnění tohoto faktoru v rámci obou Zákonů takřka identická. V obou se vliv slovosledu pretextu uplatňuje u 75 \% dokladů nepostiniciálních pozic. Je tedy evidentní, že i přes různou povahu cizojazyčných pretextů je jejich vliv na slovosledné chování enklitických forem v Bibli kralické zásadní. V případě postiniciálních pozic je však míra vlivu slovosledu cizojazyčného textu odlišná. V Novém zákoně se ukázal významný počet shod mezi českým překladem a řeckou/latinskou předlohou. Naproti tomu ve Starém zákoně se v prŕípadě postiniciálních pozic neprojevuje vliv pretextu nijak zásadně. Zůstává otevřené, co způsobilo tento rozdíl. Jednou z možností, které jsme se z rozsahových důvodů jen velmi okrajově dotkli, je to, že se zde projevují vlivy jiných (Bibli kralické předcházejících) starších českých překladů. Je známo, že Kraličtí při překladu pracovali s některými staršími biblickými překlady, a je tedy pravděpodobné, že v některých případech, $\mathrm{v}$ nichž nebyl zaznamenán vliv pretextu, mohou být reflektovány slovosledné modely starší biblické překladatelské tradice. Odpověd' na tuto otázku však musí hledat další výzkum.

\section{Prameny}

B1589-L Beza T., 1589, Testamentvm Novvm sive Nouum Foedus Iesu Christi, Genève.

B1589- $\check{R} \quad$ Beza T., 1589, Testamentvm Novvm sive Nouum Foedus Iesu Christi, Genève.

BiblKral Biblí české dil první - dil šestý. 1579-1594, Kralice.

POLY Biblia Sacra Hebraice, Chaldaice, Graece, \& Latine. 1568-1573, Antverpiae.

T-J Tremellius I., Junius F., 1579, Testamenti veteris biblia sacra ex officina typographica. 1. vyd., Francofurti ad Moenum.

\section{Literatura}

D it t m a n n R., 2012, Dynamika textu Kralické bible v české překladatelské tradici. Olomouc: Refugium Velehrad-Roma s. r. o.

G e b a u e r J., 1896, Historická mluvnice jazyka českého III/1. Tvarosloví, skloňování, Praha.

H a v ránek B., 1928, Genera verbi v slovanských jazycích 1, Praha: Královská česká společnost nauk.

K o m á r e k M., 1981, Nástin morfologického vývoje českého jazyka, Praha: SPN

K o s e k P., 2011, Enklitika v češtině barokní doby, Brno: Host.

K o s e k P., Č e ch R., N a v rátil ová O., 2018a, Starobylá dativní enklitika "mi«, »si«, »ti« ve staročeské bibli 1. redakce. In P. Malčík (Vyd.), Vesper Slavicus. Sborník k nedožitým devadesátinám prof. Radoslava Večerky, Praha: Nakladatelství Lidové Noviny, s. 137-151.

K o s e k P., Č e c h R., N a v rát i l o vá O., 2018b, Slovosled staročeských pronominálních enklitik závislých na VF ve staročeské bibli 1. redakce, „Slavia” 87(1-3), s. 189-204.

K o s e k P., Č e c h R., N a v rátil ová O.,2020, The influence of the Latin pretex on the word order of pronominal enclitics in the 1st edition of the Old Czech Bible. In S. Birzer, I. Mendoza (Hrsg.), Diachronic Slavonic Syntax 3: Traces of Latin, Greek and Church Slavonic in Slavonic Syntax, v tisku.

Kos e k P., Č e ch R., N a vráti l ová O., H orák M., 2020, Slovosled pronominálnich enklitik mi, si, ti, ho, mu závislých na verbu finitu v prvním vydáni Bible kralické, v tisku.

Kosek P., Č e ch R., Navrátilová O., Mačutek J., 2018a, On the Development of Old Czech (En) clitics, „Glottometrics” 40/1, s. 51-62.

K o s e k P., Č e ch R., N a vrátil ová O., M a čutek J., 2018b, Word order of reflexive sě in finite verb phrases in the first edition of the Old Czech Bible translation, „Studia Linguistica Universitatis Iagellonicae Cracoviensis” 133, nr 3, s. 177-200.

K y a s V., 1997, Česká Bible v dějinách národního písemnictví. Praha: Vyšehrad.

To m a n J., 2000, Prosodické spekulace o klitikách v nekanonických pozicích. In Z. Hladká, P. Karlík (eds.), Čeština, univerzália a specifika 2, s. 161-166.

T o ma n J., 2004, Ertlova diskuse českých klitik. In Z. Hladká, P. Karlík (eds.), Čeština, univerzália a specifika 5, Brno, s. 73-79.

V ážný V., 1964, Historická mluvnice česká II. Tvarosloví 1. Skloňování, Praha: SPN 